University of Nebraska - Lincoln

DigitalCommons@University of Nebraska - Lincoln

\title{
Cow dogs: Use of livestock protection dogs for reducing predation and transmission of pathogens from wildlife to cattle
}

\author{
Kurt C. Vercauteren \\ USDA-APHIS-Wildlife Services, kurt.c.vercauteren@usda.gov \\ Michael J. Lavelle \\ USDA/APHIS/WS National Wildlife Research Center, michael.j.lavelle@aphis.usda.gov \\ Thomas M. Gehring \\ Central Michigan University \\ Jean-Marc Landry \\ Institute for the Promotion and Research on Guarding Animals
}

Follow this and additional works at: https://digitalcommons.unl.edu/icwdm_usdanwrc

Part of the Life Sciences Commons

\begin{abstract}
Vercauteren, Kurt C.; Lavelle, Michael J.; Gehring, Thomas M.; and Landry, Jean-Marc, "Cow dogs: Use of livestock protection dogs for reducing predation and transmission of pathogens from wildlife to cattle" (2012). USDA Wildlife Services - Staff Publications. 1245.

https://digitalcommons.unl.edu/icwdm_usdanwrc/1245
\end{abstract}

This Article is brought to you for free and open access by the U.S. Department of Agriculture: Animal and Plant Health Inspection Service at DigitalCommons@University of Nebraska - Lincoln. It has been accepted for inclusion in USDA Wildlife Services - Staff Publications by an authorized administrator of DigitalCommons@University of Nebraska - Lincoln. 


\title{
Cow dogs: Use of livestock protection dogs for reducing predation and transmission of pathogens from wildlife to cattle
}

\author{
Kurt C. VerCauteren ${ }^{\mathrm{a}, *}$, Michael J. Lavelle ${ }^{\mathrm{a}}$, Thomas M. Gehring ${ }^{\mathrm{b}}$, Jean-Marc Landry ${ }^{\mathrm{c}}$ \\ a National Wildlife Research Center, USDA APHIS WS, Fort Collins, CO 80521, USA \\ b Department of Biology, Central Michigan University, Mount Pleasant, MI 48859, USA \\ c Institute for the Promotion and Research on Guarding Animals, Martigny, Switzerland
}

\section{A R T I C L E I N F O}

\section{Article history:}

Accepted 6 June 2012

Available online 12 July 2012

Keywords:

Cattle

Depredation

Disease

Livestock protection dog

\begin{abstract}
A B S T R A C T
Dogs have been employed to protect an array of resources from various species of offending wildlife. Historically, livestock protection dogs (LPDs) protected domestic sheep and goats from predators based on development of a strong bond between protected and protector. Within reason, developing that bond between a LPD and other species of livestock should be achievable. We conducted several studies in which we raised and bonded LPDs with bovine calves and evaluated them for protecting cattle in a variety of settings. Though successful strategies in developing LPDs to protect cattle were similar to those established for sheep, we found differences that were important for optimizing the process. Here we outline our strategies for developing LPDs for maintaining separation between cattle and wild ungulates that are reservoirs of disease that cattle are susceptible to as well as wild carnivores that are predators of cattle.
\end{abstract}

(C) 2012 Published by Elsevier B.V.

\section{Introduction}

Livestock are susceptible to adverse impacts of wildlife through transmission of pathogens, predation, and competition for resources. Issues pertaining to predation have typically been associated with sheep; however, predation on calves and occasionally adult cattle occurs and is on the rise as gray wolf (Canis lupus) populations increase and expand in geographic range in the USA (Mech et al., 1995; Gehring and Potter, 2005; Harper et al., 2005; Bangs et al., 2006; Edge et al., 2011) and parts of Europe (Landry et al., 2005). Livestock protection dogs (LPDs) have been used in Europe and Asia for thousands of years to minimize predation on sheep and goats (Landry et al., 2005; Gehring et al., 2006, 2010a; VerCauteren et al., 2008a). Livestock producers have successfully demonstrated LPDs can reduce

\footnotetext{
* Corresponding author at: USDA APHIS WS, National Wildlife Research Center, 4101 LaPorte Avenue Fort Collins, CO 80521-2154, USA. Tel.: +1 970266 6093; fax: +1970266 6089 .

E-mail address: kurt.c.vercauteren@aphis.usda.gov (K.C. VerCauteren).
}

predation based on the development of bonds between LPDs and associated livestock (e.g., Coppinger et al., 1988; Urbigkit and Urbigkit, 2010), though means for accomplishing this with cattle and other domestic animals have received little attention (Messerschmidt, 1983; Coppinger et al., 1988; Landry, 1999; Rigg, 2001, 2004). Much empirical knowledge of LPDs was lost due to the eradication of predators in several areas of Europe (e.g., Switzerland, France, and Germany) and the collectivization agricultural policies that arose under communist regimes though this knowledge is now being revived by conservation organizations (Landry, 1999). Use of LPDs in the USA began more recently with a peak in popularity in the 1970s as lethal methods of predator control (primarily of coyotes; Canis latrans) became restricted (Arons, 1980; Messerschmidt, 1983; Green and Woodruff, 1999). Word-wide interest and use of LPDs is currently increasing again partly because wolf recovery has proven successful in parts of Europe and Western USA (Landry et al., 2005; Urbigkit and Urbigkit, 2010, respectively).

Competition for resources between livestock and wild ungulates pertains to both standing forage and stored 
feed that is simply consumed or contaminated by wildlife resulting in waste (Palmer et al., 2001, 2004; VerCauteren et al., 2003; Van Campen and Rhyan, 2010). Abundant wildlife populations such as white-tailed deer (Odocoileus virginianus) in many regions of the USA (Palmer et al., 2004) and wild boar (Sus scrofa) in Europe (Gortazar et al., 2005, 2007) have created disease-related challenges for livestock producers. Contaminated resources such as food and water contribute to potential for transmission of pathogens (Bengis et al., 2002; Miller et al., 2004). Risk of pathogen transmission between wildlife and livestock has shown to be particularly challenging with diseases such as bovine tuberculosis and brucellosis (Gortazar et al., 2005, 2007; Rhyan and Spraker, 2010; Van Campen and Rhyan, 2010). Livestock are at risk of contracting bovine tuberculosis from free-ranging wildlife reservoirs through sharing common resources (Palmer et al., 2004; Gortazar et al., 2005; O’Brien et al., 2006; Palmer and Whipple, 2006; Van Campen and Rhyan, 2010).

Lethal population reductions of wildlife host species are oftentimes used as mitigation strategies for reducing potential for spread of disease (Harrison et al., 2010). There is, however, a growing need for the development and evaluation of non-lethal tools for alleviating damage due to wildlife (Shivik, 2006; Hawley et al., 2009; Edge et al., 2011). Exclusionary devices have been evaluated for keeping deer from contaminating cattle feed (e.g., Seward et al., 2007); however, these devices can be expensive, can fail, and must be maintained to remain functional to be effective. Non-lethal tools such as LPDs are receiving increased consideration as viable management options, though like other non-lethal strategies may be most effective when used in conjunction with lethal means (Bangs et al., 2006; Gehring et al., 2006; Shivik, 2006). Researchers have demonstrated the abilities of dogs for protecting various resources of value to humans from wildlife including: forest plantations (Beringer et al., 1994), golf courses (Woodruff and Green, 1995), office complexes (Castelli and Sleggs, 2000), orchards (Curtis and Rieckenberg, 2005), and vegetable farms (VerCauteren et al., 2005).

Researchers documented the occurrence of LPDs pursuing free-ranging ungulates while protecting grazing livestock, thus demonstrating potential for excluding species not traditionally targeted (Coppinger et al., 1988; Hansen and Bakken, 1999; Marker et al., 2005). To this end, we theorized that LPDs raised and bonded to cattle may have potential to be used to protect cattle from an array of wildlife-related risks. For various studies and management efforts over a period of a decade, we raised 41 LPDs for protecting cattle from predation and disease harbored in wild ungulates. Within this review we assimilate our experiences employing LPDs with cattle through our efforts in the USA and Europe. We present strategies for raising and integrating LPDs into cattle operations and demonstrate their effectiveness against predators and potential for reduction in transmission of pathogens. Conversely, we also present some disadvantages of using LPDs. Though it must be realized that each producer's operation and wildlife damage needs vary, we believe our experiences provide a general strategic plan from which others can derive their own tactics for developing LPDs to be used with cattle.

\section{Approach to raising effective LPDs}

The use of LPDs with cows is novel in many regions, thus proven preparation strategies are limited. As such, we emphasize the importance of taking a flexible and adaptive approach to raising and training LPDs. Further, a joint commitment by promoters and producers is necessary for helping resolve problems and ensuring successful steps in preparing LPDs are taken. We found that thoughtful preparation and integration of LPDs into working cattle operations was essential to success. As such, discussions with producers hosting our research revealed the extent of variability among LPD deployments and the importance of following particular established guidelines. Methods used in our studies were the result of other's published methods, discussions with reputable LPD breeders and trainers, adaptations based on our experiences, and were approved by our corresponding Institutional Animal Care and Use Committees. Regardless of the methods used, all LPDs are individuals and some do not perform as effective guardians (Table 1) and must be relieved of their duties.

\subsection{General training strategies}

General training strategies of LPDs can vary considerably and impact how effective individual LPDs will be (Rigg, 2001). Training begins with bonding, which is the creation of a close association between the protected and protector and determines what the dog will protect and remain with later in life (Sims and Dawydiak, 2004). We found traditional strategies emphasized the importance of minimal human interaction with dogs to minimize desire for associating with humans (Lorenz and Coppinger, 1987; Green and Woodruff, 1999; Hansen and Smith, 1999). Too much human interaction has potential to render LPDs less effective in protecting livestock due to of lack of motivation to remain with cattle and desire to be with humans. It is important, though that pups are familiarized enough with producers that they can be caught and handled for training, transport, and routine health care (Table 1 ). If producers are unable to handle or even catch their LPDs, they cannot effectively perform required activities such as but not limited to, medicating or moving LPDs as needed (e.g., Landry et al., 2005; Urbigkit and Urbigkit, 2010).

By and large, we prepared pups according to methods described by Lorenz and Coppinger (1987), Green and Woodruff (1990, 1999), and Sims and Dawydiak (2004) for protecting sheep and goats, though adapted procedures to better fit cattle production systems. As recommended by Green and Woodruff (1999), we taught basic commands (i.e., come, no, back to the herd) and trained our pups to accept being leashed and transported in dog crates and vehicles. Aggressive interactions with calves were not acceptable (e.g., biting, pulling tails, or playing aggressively) and were corrected immediately with verbal reprimand. For research purposes and due to the landscape of small properties we worked on in USA studies, pups were spayed at 6 months of age or neutered at 9 months 
Table 1

Common problem behaviors encountered with employing livestock protection dogs and methods for correction (with references) as observed during research directed at protecting cattle from wildlife-related risks in USA and Europe.

\begin{tabular}{|c|c|c|c|c|}
\hline Problem behavior & Caused by & Remedied by & Avoided by & References \\
\hline Roaming & $\begin{array}{l}\text { Too much human } \\
\text { attention; intact dog; } \\
\text { female in heat; too much } \\
\text { motivation to hunt } \\
\text { wildlife; weak bond with } \\
\text { flock; companion dog } \\
\text { moved to another herd }\end{array}$ & $\begin{array}{l}\text { Erect electric or invisible } \\
\text { fence, spay/neuter, shock } \\
\text { collar, replace with } \\
\text { flock/herd-oriented breed } \\
\text { or individual }\end{array}$ & $\begin{array}{l}\text { Provide only necessary } \\
\text { attention, raise with } \\
\text { effective LPD, spay/neuter, } \\
\text { retain dog with the herd } \\
\text { from beginning }\end{array}$ & $\begin{array}{l}\text { Sims and Dawydiak } \\
\text { (2004), Green and } \\
\text { Woodruff (1999), Rigg } \\
\text { (2004), Landry et al. } \\
\text { (2005), VerCauteren } \\
\text { et al. (2008a), Gehring } \\
\text { et al. (2010b) }\end{array}$ \\
\hline $\begin{array}{l}\text { Aggression toward } \\
\text { livestock }\end{array}$ & $\begin{array}{l}\text { Lack of early discipline; } \\
\text { immaturity; play behavior; } \\
\text { adolescent phase of } \\
\text { ontogeny development }\end{array}$ & $\begin{array}{l}\text { Increased attention and } \\
\text { reprimand, time, shock } \\
\text { collar, replace with less } \\
\text { aggressive breed or } \\
\text { individual, remove from } \\
\text { livestock and temporarily } \\
\text { place in herd with more } \\
\text { aggressive livestock (e.g., } \\
\text { heifers or adults), provide } \\
\text { toys }\end{array}$ & $\begin{array}{l}\text { Consistent reprimand for } \\
\text { chasing, raise with } \\
\text { effective LPD, employ } \\
\text { appropriate breed, } \\
\text { minimize potential for } \\
\text { boredom }\end{array}$ & $\begin{array}{l}\text { Green and Woodruff } \\
\text { (1988), Sims and } \\
\text { Dawydiak (2004), } \\
\text { Green and Woodruff } \\
\text { (1999), Hansen and } \\
\text { Bakken (1999), Rigg } \\
(2001,2004)\end{array}$ \\
\hline $\begin{array}{l}\text { Aggression toward } \\
\text { humans }\end{array}$ & $\begin{array}{l}\text { Underlying breed } \\
\text { characteristics or lack of } \\
\text { socialization; territorial } \\
\text { behavior; protecting } \\
\text { object, food or female; } \\
\text { novel behavior of humans } \\
\text { towards LPDs; learned } \\
\text { aggressive behavior; pack } \\
\text { behavior; fearful } \\
\text { temperament }\end{array}$ & $\begin{array}{l}\text { Replace with less } \\
\text { aggressive dog or breed; } \\
\text { increased attention and } \\
\text { reprimand, time, shock } \\
\text { collar, display warning } \\
\text { signs, replace with less } \\
\text { aggressive breed, } \\
\text { enrichment of } \\
\text { environment occupied by } \\
\text { puppy during socialization }\end{array}$ & $\begin{array}{l}\text { Employ appropriate breed, } \\
\text { provide adequate levels of } \\
\text { socialization with humans } \\
\text { and environment (i.e., } \\
\text { avoid the withdrawal } \\
\text { symptom) }\end{array}$ & $\begin{array}{l}\text { Green and Woodruff } \\
\text { (1988), Green and } \\
\text { Woodruff (1990, 1999), } \\
\text { Sims and Dawydiak } \\
\text { (2004), Hansen and } \\
\text { Bakken (1999), Rigg } \\
\text { (2001) Urbigkit and } \\
\text { Urbigkit (2010) }\end{array}$ \\
\hline $\begin{array}{l}\text { Lack of concern } \\
\text { over offending } \\
\text { species }\end{array}$ & $\begin{array}{l}\text { Lack of training or too } \\
\text { much pressure by } \\
\text { offending species; dog too } \\
\text { young; weak } \\
\text { temperament; female in } \\
\text { heat; wounds (e.g. paws) }\end{array}$ & $\begin{array}{l}\text { Provide supplemental } \\
\text { training with } \\
\text { encouragement to address } \\
\text { target species, place dog in } \\
\text { a pack of experienced dogs } \\
\text { or provide an experienced } \\
\text { dog, ensure high quality } \\
\text { food (enough energy and } \\
\text { proteins) and health (e.g., } \\
\text { internal parasites) }\end{array}$ & $\begin{array}{l}\text { Provide early } \\
\text { encouragement to exclude } \\
\text { target species, employ } \\
\text { appropriate breed, give } \\
\text { appropriate food, regular } \\
\text { heath care }\end{array}$ & $\begin{array}{l}\text { Coppinger et al. (1987), } \\
\text { Rigg (2001), Landry } \\
\text { (1999), VerCauteren } \\
\text { et al. (2008a) }\end{array}$ \\
\hline $\begin{array}{l}\text { Insufficient } \\
\text { protection against } \\
\text { offending species }\end{array}$ & $\begin{array}{l}\text { Underlying breed } \\
\text { characteristics; illness; } \\
\text { female in heat; not enough } \\
\text { dogs; environmental } \\
\text { factors (e.g., wooded areas, } \\
\text { weather) }\end{array}$ & $\begin{array}{l}\text { Replace with dog or breed } \\
\text { that is more aggressive } \\
\text { towards predators, regular } \\
\text { health care, incorporate } \\
\text { alternative prevention } \\
\text { tools (e.g., electrified fence, } \\
\text { calving in protected zones) }\end{array}$ & $\begin{array}{l}\text { Employ appropriate breed, } \\
\text { rear in area with offending } \\
\text { species, monitor health, } \\
\text { supply with alternative } \\
\text { prevention tools, employ } \\
\text { more dogs }\end{array}$ & $\begin{array}{l}\text { Green and Woodruff } \\
\text { (1988), Sims and } \\
\text { Dawydiak (2004), } \\
\text { Andelt (1999), Green } \\
\text { and Woodruff (1999), } \\
\text { Rigg (2001) Urbigkit } \\
\text { and Urbigkit (2010) }\end{array}$ \\
\hline $\begin{array}{l}\text { Lack of obedience } \\
\text { and ability to } \\
\text { handle }\end{array}$ & $\begin{array}{l}\text { Insufficient training during } \\
\text { the } 7-12 \text { months period; } \\
\text { fearful temperament }\end{array}$ & $\begin{array}{l}\text { Increase frequency of } \\
\text { training, maintaining } \\
\text { regular contacts until the } \\
\text { dog is adult, avoid fearful } \\
\text { pups }\end{array}$ & $\begin{array}{l}\text { Provide early and } \\
\text { consistent training until } \\
\text { adult and adequate level of } \\
\text { socialization with handlers }\end{array}$ & $\begin{array}{l}\text { Green and Woodruff } \\
(1990,1999), \text { Sims and } \\
\text { Dawydiak (2004), } \\
\text { Landry et al. (2005) }\end{array}$ \\
\hline $\begin{array}{l}\text { Lack of } \\
\text { attentiveness } \\
\text { toward livestock }\end{array}$ & $\begin{array}{l}\text { Insufficient or bonding too } \\
\text { late; illness; female in } \\
\text { heat; old dogs }\end{array}$ & $\begin{array}{l}\text { Replace with effective dog, } \\
\text { medical checkup }\end{array}$ & $\begin{array}{l}\text { Follow recommended } \\
\text { bonding procedures, } \\
\text { monitor health }\end{array}$ & $\begin{array}{l}\text { Sims and Dawydiak } \\
\text { (2004), Andelt (1999), } \\
\text { Green and Woodruff } \\
\text { (1999), Hansen and } \\
\text { Smith (1999), Rigg } \\
\text { (2004), Marker et al. } \\
\text { (2005) }\end{array}$ \\
\hline $\begin{array}{l}\text { Ineffective } \\
\text { protection }\end{array}$ & $\begin{array}{l}\text { Insufficient bonding; } \\
\text { illness; too large of an area; } \\
\text { too much pressure }\end{array}$ & $\begin{array}{l}\text { Replace with effective dog, } \\
\text { medical checkup, disperse } \\
\text { resources: food, water, and } \\
\text { shelter; employ additional } \\
\text { dog (s), employ other } \\
\text { prevention tools }\end{array}$ & $\begin{array}{l}\text { Employ appropriate breed, } \\
\text { raise in area with offending } \\
\text { species, monitor health, be } \\
\text { aware of limits of the dog }\end{array}$ & $\begin{array}{l}\text { Sims and Dawydiak } \\
\text { (2004), Andelt (1999), } \\
\text { Green and Woodruff } \\
\text { (1999), Rigg (2001), } \\
\text { Urbigkit and Urbigkit } \\
\text { (2010) }\end{array}$ \\
\hline $\begin{array}{l}\text { Insufficient } \\
\text { patrolling of area } \\
\text { to be protected }\end{array}$ & $\begin{array}{l}\text { Too large of area; lack of } \\
\text { encouragement to } \\
\text { establish territory }\end{array}$ & $\begin{array}{l}\text { Disperse resources: food, } \\
\text { water, and shelter; provide } \\
\text { encouragement to explore } \\
\text { territory; replace with } \\
\text { more territorial breed }\end{array}$ & $\begin{array}{l}\text { Conduct routine walks } \\
\text { with dog on lead within } \\
\text { area to be protected }\end{array}$ & $\begin{array}{l}\text { Sims and Dawydiak } \\
\text { (2004), Green and } \\
\text { Woodruff (1999), } \\
\text { VerCauteren et al. } \\
\text { (2008a) }\end{array}$ \\
\hline
\end{tabular}


to reduce the desire to roam and leave the herd (Green and Woodruff, 1999; VerCauteren et al., 2008a). Spaying and neutering also reduces potential for producing unplanned and minimally habituated pups.

\subsection{Preparing for arrival of pups}

Through 14 independent occasions with 35 total LPD pups ( 4 individuals, 7 pairs, and 3 litters with total of 17 pups), we raised pups with cattle (VerCauteren et al., 2008a; Gehring et al., 2010b). The remaining 6 pups were raised with sheep ( 1 as a litter of 4 and 2 independently) and later transitioned to cattle. Raising pups with cattle versus sheep or goats differs in that small and relatively delicate pups must be protected from cattle and even calves. Sheer size and weight of cattle imposes serious risk for injury to pups, especially during early stages when pups are naïve and lacking agility. We recommend acquiring a pair of young calves ( $<1$ month of age) to accompany the new pup to adulthood. When raised with cattle, we provided pups with a small ( $\left.2-8 \mathrm{~m}^{2}\right)$ refuge constructed of rigid fence panels (0.86 $\mathrm{m}$ in height) with an access opening too small for passage by calves but accessible by pups where clean straw, dog food, and water were available.

\subsection{Bonding LPDs to livestock}

Training pups to protect cattle is similar to preparing them to protect sheep or goats as it is based on establishing a strong bond. Older literature states that between 3 and 12 weeks of age pups will bond with siblings, parents, or other adults, but they can also bond with other social species (Scott, 1962; Scott and Fuller, 1965; Fox and Stelzner, 1966; Hansen and Smith, 1999). Beyond 16 weeks, bonding with other species is rarely successful (Freedman et al., 1961; Scott and Fuller, 1965). This limited window for socialization also varies by breed and individual.

We initiated the bonding process by housing recently weaned pups at 6-10 weeks of age individually with 2 calves (<1 week old) (Green and Woodruff, 1999; Sims and Dawydiak, 2004; VerCauteren et al., 2008a). Our calves were no longer with their dams, thus they relied on bottle feeding for nourishment and were fed twice daily in the presence of pups. Based on behaviors observed, we believe our adult LPDs in general were socialized and well bonded with cattle and we felt the bottle feeding regime provided an excellent opportunity for bonding with calves, as physical and social contact enhanced the bond. As we bottle fed calves, pups persistently licked and cleaned muzzles of the calves, which provided a great deal of gentle physical contact (Fig. 1). Calves became equally interested in LPDs and would suck on their ears and collars without the LPDs exhibiting any aggressive or play behavior. Additionally, pups would sleep immediately next to their calves (Fig. 2). Pups should ideally remain with the livestock they were reared with to facilitate transitioning into new locations and herds (Green and Woodruff, 1999).

At 6-7 months of age, we initiated an acclimation process to familiarize pups with pastures they would eventually occupy. Pups were kept with their calves within pastures daily and returned to their smaller confines by

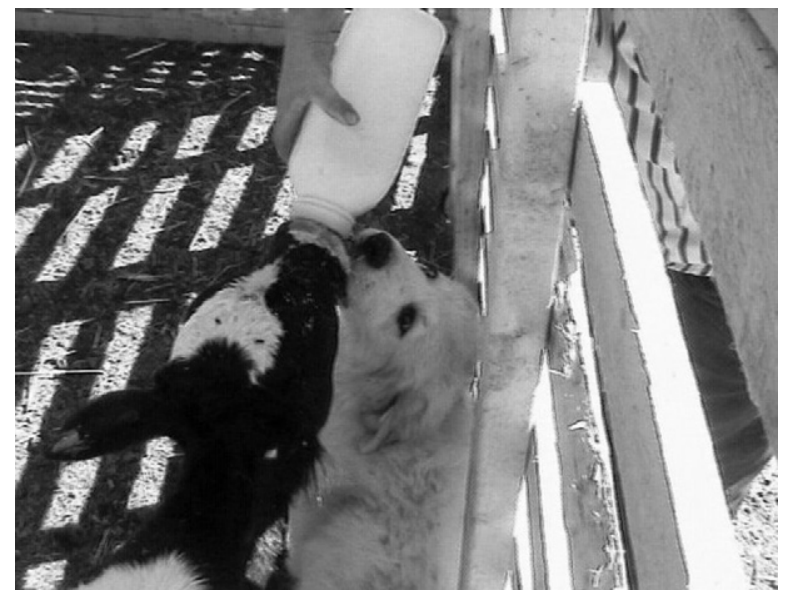

Fig. 1. Physical contact and bonding between calf and livestock protection pup used to protect cattle from wildlife-related risks in USA and Europe (Photograph: Michael Lavelle).

dusk. In attempts to foster territoriality in pups, we walked perimeters of pastures with leashed pups daily. These walks around the inside of pastures also helped to establish the fence as a boundary. After 10-14days of this daily transitional training, pups were released into pastures full time and were no longer under constant supervision (VerCauteren et al., 2008a; Gehring et al., 2010c).

\subsection{Integrating LPDs into herds}

At 7 months, we began an integration program for introducing pups and their calves into larger pastures with more livestock. We maintained original pup-calf groups throughout our research to ease this transition into larger groups with naïve individuals. If introduced into herds familiar with LPDs, they can typically move about safely; however, we discourage introducing naïve LPDs to adult cows before 3-4 months to ensure they are nimble enough to avoid injury.

We introduced pups to cows and calves in confinement to encourage interaction between them while monitoring

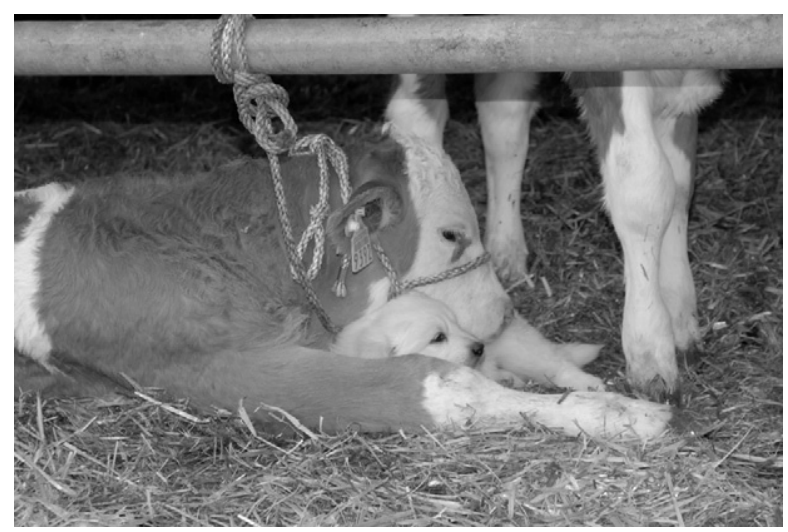

Fig. 2. Demonstration of the strong bond being developed by a livestock protection pup and a calf it will later protect from wildlife-related risks in USA and Europe (Photograph: Jean-Marc Landry). 


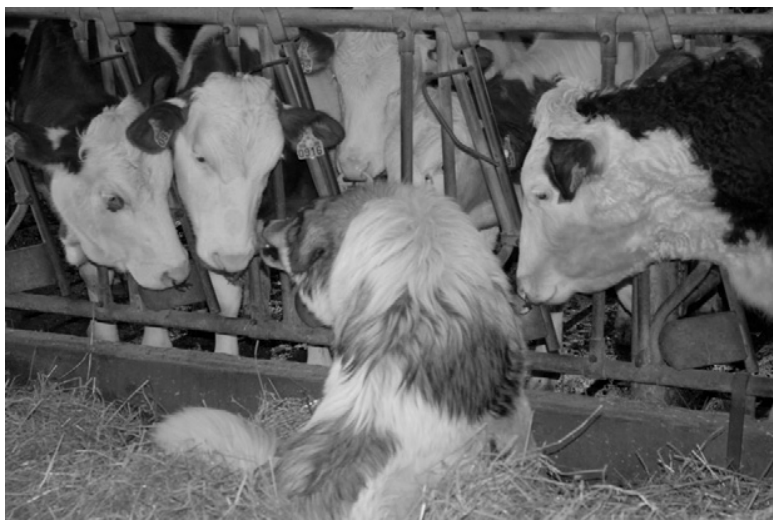

Fig. 3. Bonding behavior demonstrated by an adult livestock protection dog used to protect cattle from wildlife-related risks in USA and Europe (Photograph: Jean-Marc Landry).

for aggressive behavior. As the concept of bonding LPDs to cattle was relatively new in Switzerland, we started our first litter of pups $(n=4)$ in a flock of sheep and later transitioned them to cattle at 3-6months of age. The pups quickly sought to interact with the calves, which demonstrated varied reactions. As adult cattle became accustomed to the presence of LPDs, they greeted LPDs or freely grazed without being disturbed by them and would be found resting and sleeping together. Once released into pastures with LPD-naïve adult cattle, LPDs would greet cattle in a submissive fashion, often licking around the muzzles of cattle (Fig. 3). We noted one situation where a LPD stayed within a few meters of a cow giving birth. The LPD did not interfere and appeared relaxed, as did the cow. Once the calf was born and got to its feet, the LPD greeted and licked it and still the cow showed no aggressive behavior toward the LPD.

\subsection{Containment}

Husbandry practices used by producers directly impact the likelihood of predation and general success of LPDs (Espuno et al., 2004). Whether or not a LPD stays with the livestock to be protected and related confines remains one of the most important factors contributing to success of using LPDs as well as their health and safety. Thus, we had no tolerance for LPDs roaming and incorporated dog-containment systems on properties that had potential for or demonstrated problems with LPDs leaving pastures (Gehring et al., 2010c). When LPDs are treated like pets and allowed to spend time away from cattle they may shift their focus from cattle to the comfort and attention associated with a producer and home place.

Over $25 \%$ of sheep producers in the USA graze primarily on open rangeland (Green et al., 1984; Urbigkit and Urbigkit, 2010) and more than 18,000 grazing leases and permits are held by cattle and sheep producers on lands managed by the Bureau of Land Management alone (Idaho Rangeland Resource Commission, 2010). Flocks travel long distances across hundreds of kilometers of rangeland with free-ranging LPDs occasionally moving among flocks or congregating within a single flock (Urbigkit and Urbigkit,
2010). This roaming behavior would be a key concern for producers in regions such as Midwestern USA and European Alps where landholdings are smaller, human densities are greater, and road densities are high. To remedy roaming behavior, we present a variety of containment techniques below.

To determine the best and most cost-effective option for containing LPDs and cattle in pastures, producers need to consider existing infrastructure and management practices. We found that existing livestock fences provided a visible boundary that facilitated the LPD training processes. However, when existing fences proved insufficient, we added strands of electrified 12-ga wire to existing perimeter fences $(0.25 \mathrm{~m}$ from the ground $)$ to help contain LPDs. Additional strands were added as needed to achieve complete containment. We monitored fences regularly and maintained them at $7000 \mathrm{~V}$. We also opportunistically reinforced respect for electric fences and corrected escape behavior by providing physical contact between LPDs and electric fences. We sought to do so in a subtle way to provide negative stimuli and reinforce respect for boundaries while minimizing any association with our presence.

Electric dog-containment systems facilitate this process by functioning independent of the presence of trainers, which minimizes the potential for negative association with handlers (Schilder and van der Borg, 2004). The use of electrical stimulation has been established as an effective means for teaching animals to avoid particular behaviors or locations (Rushen, 1986; Schilder and van der Borg, 2004; Lee et al., 2007). Further, collars that deliver negative stimuli have proven effective in triggering targeted behavioral outcomes in a variety of species (Schilder and van der Borg, 2004; Schultz et al., 2005; Hawley et al., 2009; Rossler et al., 2012). We achieved successful containment and ensured safety of LPDs with in- or on-ground installation of Invisible Fence ${ }^{\circledR}$ systems (e.g., Invisible Fence and Computer Collar $^{\circledR}$, Invisible Fence Brand, Knoxville, TN, USA; Coppinger et al., 1987; Landry et al., 2005; VerCauteren et al., 2008a; Gehring et al., 2010c). We placed the boundary fence wire outside livestock fencing (either lying on the ground or hung on fence posts), around the entire perimeter (as extensive as $2530 \mathrm{~m}$ ). Dogs were outfitted with a collar that emitted an audible alarm followed by a corrective shock if LPDs continued to approach within a pre-determined distance $(0.30 \mathrm{~m}$ in our situation $)$ of the fenceline. Contact points where electrodes in the collars contact skin of the dog's neck were examined frequently (twice per week) to ensure they were not abrading the skin and risking infection. We conducted training with LPDs to build respect for boundaries with containment systems according to methods recommended by fence manufacturers. At several farms we did not have access to electricity thus powered fence systems with $12-\mathrm{V}$ deepcycle marine batteries. In remote sites, we incorporated solar panels into fence systems minimizing the need to exchange batteries. At research sites lacking livestock fence, we constructed electrified poly-wire fences (e.g., IntelliTwine $^{\mathrm{TM}}$, Premiere1 Supplies, Washington, IA, USA) to contain cattle, which also proved beneficial in establishing boundaries for LPDs. For more detailed information on 
fencing options see VerCauteren et al. (2008a) and Gehring et al. (2010b).

\section{Discussion of findings}

\subsection{LPD behaviors}

Efficacy of LPDs is based on their social nature and ability to bond livestock they are raised with. Further, LPDs do not necessarily protect areas in which they occupy; however, they protect the livestock and area occupied at that time. Our LPDs exhibited protective behaviors by barking at and chasing deer, wolves, and other wildlife from pastures. Livestock protection dogs often display an approach-withdrawal behavior in which they rapidly confront perceived danger but then retreat to the group of animals they are protecting (Beringer et al., 1994). This behavior may be particularly beneficial in minimizing direct contact and associated risk of transmission of pathogens. Solitary LPDs oftentimes will only pursue a wolf for a short duration (about $5 \mathrm{~s}$; J.-M. Landry, Institute for the Promotion and Research on Guarding Animals [IPRGA]). Conversely, paired LPDs will pursue a wolf longer (about $40 \mathrm{~s}$ ) and farther (about $2 \mathrm{~km}$; J.-M. Landry, IPRGA).

In general, we recommend raising pups which are intended to work solo individually to avoid a shift of the social needs to another pup. Yet, when more than one dog is going to be used in a herd, building the bond between dogs is important and can be facilitated through raising pups concurrently. However, only after the bond between pup and livestock is strong enough (typically $2-3$ months), is it then advisable to allow interactions between pups. It can be difficult to train two pups simultaneously, especially if they begin to abandon the herd. In particular situations, integrating pups into a herd can be facilitated by introducing a pup to livestock in the presence of an established adult LPD. For example, we utilized this technique with a young dog (5 months old) that was unsuccessfully integrated into a cow-calf herd previously. The young dog followed the adult dog and eventually bonded successfully with the cows. On two other occasions, we successfully integrated adult LPDs that were initially bonded with sheep into cattle herds. In the first case, the sheep producer steadily decreased the number of sheep, while increasing the number of cows. The dog readily bonded to the cows and protected them (C. Zaïre, La Pastorale Pyrénéenne, unpublished report).

As mentioned previously, roaming is an unacceptable behavior that should be prevented in all cases and a guideline we emphasize must be followed. We documented two LPDs that abandoned their herds and began to chase and kill livestock nearby and had to be euthanized (J.-M. Landry, IPRGA, unpublished report). This situation also emphasizes the importance of routine monitoring and maintenance of LPDs required of producers to ensure success.

Individual dogs demonstrate particular behaviors, thus selecting individuals that complement one another based on their particular behaviors can be advantageous when utilizing more than one dog to protect a herd. Specific breeds also demonstrate different behaviors that may be more or less beneficial based on the desired type of protection. For example, Great Pyrenees are one of the LPD breeds being least aggressive toward humans and may prove best suited for smaller private pastures and on publically owned rangelands where potential for interaction with neighbors or other land users is likely (Green and Woodruff, 1988; Hansen and Bakken, 1999; Landry et al., 2005; Urbigkit and Urbigkit, 2010). However, these more commonly used and less aggressive breeds (e.g., Great Pyrenees and Akbash) are more vulnerable to threats posed by significant predators such as offending wolf packs, emphasizing that appropriate dogs for applications involving larger predators (i.e., wolves and grizzly bears) must remain non-human aggressive, yet need to be canine aggressive (Urbigkit and Urbigkit, 2010). Such breeds (e.g., Central Asian Ovcharka, Transmontano Mastiff, Karakachan, Kangal, and Shar Planinetz) originate from areas with large carnivores (providing unique experience) and are of large body size. As such, breed selection and number of LPDs to employ should be based on likely adversaries and characteristics of surrounding environment (Landry and Raydelet, 2010).

In tourist-inhabited areas like American Rocky Mountains or European Alps or Jura Mountains, aggression by LPDs towards companion dogs, hikers, bikers, and other land users may occur and is unacceptable. In the event of outright aggression toward other users of public lands, the particular LPD involved should be removed from duty on public lands. In these areas, we highly recommend the use of signage to alert and educate users to the presence of LPDs. Education of humans is needed to encourage their respect of fences, and so they avoid alarming LPDs by disturbing the livestock being protected.

We observed that behaviors of LGDs greatly affected the behavior of their cows. Cattle can also respond aggressively to predators, apparently in response to particular dog vocalizations (J.-M. Landry, IPRGA, unpublished report). Some dogs moved in a way that cows did not react to at all (usually LPDs which were born into cow herds or got a long habituation to them during their adulthood). Surprisingly, one LPD raised with sheep and not familiar with cows behaved like LPDs raised with cattle and was quickly "accepted" by the herd. Our observations suggest that it is easier and safer to introduce a LPD with calves or heifers, than with adult cows, and especially cows with calves. The specific calves we started our pups with remained with them throughout our research (2-4 years) which we believe later eased transition into larger herds. We found naïve cattle to quickly accept the presence of our LPDs and associated calves.

\subsection{Disease mitigation}

Our studies in the USA were focused on minimizing interactions between cattle and white-tailed deer due to potential risk of pathogen transmission in which we used opportunities when dogs demonstrated innate protective behaviors as opportunities to build upon our objectives. As such, to help establish deer as an adversary, when deer were encountered during training we demonstrated and encouraged aggression toward them by chasing and yelling. Livestock protection dogs demonstrated potential for effective control of deer interactions with cattle and minimized deer use of pastures. They were 
particularly effective in directly protecting cattle and concentrated cattle feed which is an important risk factor of bovine TB transmission on farms in the USA (VerCauteren et al., 2008a; Gehring et al., 2010b). In controlled research settings, deer visited pastures protected by LPDs less frequently and spent less time in those pastures compared to unprotected pastures (VerCauteren et al., 2008a; Gehring et al., 2010b). Deer were also deterred from approaching cattle near feed and were most often excluded elsewhere within pastures. However, the larger a given fenced pasture or the higher the local density of deer the less likely LPDs could be expected to keep deer from entering areas occupied by cattle.

\subsection{Depredation}

No livestock losses were attributed to predators on our protected farms in the USA, whereas neighboring unprotected farms experienced depredations (Gehring et al., $2010 b)$. Once LPDs were present, wolf and coyote visitation declined to zero on protected farms $(n=6)$, but increased slightly on unprotected farms ( $n=3$; Gehring et al., 2010b). On one occasion at a European site we documented predation on a herd protected by LPDs which involved a wolf attack on a cow-calf herd protected by one LPD in a wooded area. The wolves managed to separate the herd into two groups. The dog followed one, while the wolves killed (and partially consumed) three calves from the other herd.

We observed a decrease in visits by mesopredators at farms protected by LPDs compared to unprotected farms (Gehring et al., 2010b). Our personal observations and producer accounts noted occasional cases of LPD-killed mesopredators in protected pastures (opossums [Didelphis virginiana], skunks [Mephitis mephitis]; Gehring et al., 2010b, badgers [Meles meles]; J.-M. Landry, IPRGA, unpublished report). Our findings from Northern Michigan, USA and the Alps and Jura mountains of Europe suggest that LPDs bonded to cattle can protect cattle from wildliferelated threats and also reduce damage to habitat (e.g., wild boar). At European sites we observed a decrease if not the total disappearance of damage by wild boar. Wild boar can be a host for TB, thus the efficacy of LPDs against wild boar is important in reducing both damage and potential for transmission of pathogens (Gortazar et al., 2005). We also observed concurrent avoidance by red deer (Cervus elaphus) of pastures protected by LPDs and noted a decrease in damage to fences by wildlife. Coyotes (VerCauteren et al., 2008b) and raccoons (Procyon lotor; Atwood et al., 2009) are also hosts of TB and deserve attention when considering reduction of risk for transmitting pathogens to domestic livestock and exclusion through the use of LPDs.

\subsection{Benefits and considerations}

Researchers found most producers using LPDs deemed them an asset and cost-effective supplement to their management regime (Green et al., 1984; Andelt, 1992; Andelt and Hopper, 2000). Estimated annual costs associated with LPDs \$937, \$850, and \$1040/year (Landry et al., 2005; VerCauteren et al., 2008a; Gehring et al., 2010b, respectively). Although we promote LPDs as another "tool for the toolbox," they are living animals and require a long-term commitment. To the benefit of producers, this enables them to adapt to the situation at hand and learn from previous experiences. For example, a dog may learn to intercept a predator on the fringes of a herd; whereas an electronic frightening device may only be activated once the predator is into the herd. However, they are also vulnerable and can essentially be "turned off" (killed) by predators that learn their vulnerabilities. As with other tools, to be effective, they must be maintained and cared for to benefit the user. Additionally, it is the responsibility of the producer to carefully select the most appropriate tool (i.e., breed, \# of LPDs) and containment strategy to address predictable challenges and to set the stage for success. For example, issues with routine predation on a cattle herd by an established pack of wolves in vast remote country may require deployment of several LPDs and of a breed suited for such a challenging situation. In some situations simply deploying dogs may not be sufficient alone, but may also require lethal control or measures such as confinement of livestock at night. As with all non-lethal approaches to wildlife damage management, it is the responsibility of the producer to maximize potential for success by addressing issues in a timely manner and implementing an integrated system of techniques to effectively address the issue. In governmentsponsored programs, we recommend assisting producers in integrating LPDs and establishing relationships that encourage interaction with follow up visits to maximize potential for success.

\section{Conclusions}

Alternative methods for protecting cattle from a variety of disease-related threats (e.g., contaminated feed, direct contact with infected animals, etc.) are needed. Additionally, as wolves expand their range into areas overlapping with cattle production, predation will inevitably increase, furthering the demand for effective tools for protection. Non-lethal tools including LPDs are currently preferred by society over traditional lethal removal of offending individuals or entire packs and may become essential for accomplishing desired effects. The recent reappearance of LPDs on public rangelands has created challenges with user groups such as hikers and bikers that may not understand the role of LPDs in livestock protection. Education and exposure to LPDs over time will hopefully foster a more LPD-friendly environment and allow for continued expansion of their use. Successful use of LPDs is often attainable but depends upon the level of commitment of the producer as well as political and local acceptance of strategies such as using LPDs.

In our studies, LPDs demonstrated the ability to effectively protect livestock when raised with attention to details such as building strong bonds with cattle, minimizing potential to roam, and providing a suitable level of protection for the level of threat. As the use of LPDs for protecting cattle is relatively uncommon and successful strategies are not well published to date, our recommendations provide a basis for others and demonstrate the need for further research and evaluation. Livestock protection dogs could serve as a valuable, pro-active management 
tool that could be incorporated into common livestock husbandry practices to help reduce losses to predators and wildlife diseases. In the end, public acceptance and understanding as well as adaptability by all associated individuals will determine the growth and extent of use of LPDs as a valuable tool for alleviating wildlife damage.

\section{Acknowledgments}

Our work was funded by Central Michigan University (Research Excellence Fund Award), Central Michigan University College of Graduate Studies, USDA APHIS WS National Wildlife Research Center, USDA - Sustainable Agriculture Research and Education Program, Animal Welfare Institute (Christine Stevens Wildlife Award), Defenders of Wildlife, CITGO Petroleum, Inc., National Geographic Society-Conservation Trust, and the French Ministry of Agriculture (crédit d'urgence loup). We are grateful to all producers that participated, student volunteers, and A. Cellar and M. Provost for valuable field assistance. We could not have achieved the results we did without valuable consultations with R. Coppinger, C. de La Cruz, K. Woods, J. Green, and R. Woodruff. Expertise and care provided by breeders including P. Brunkala, J. Ketcham, M. McGuire, and F. Wenger was essential.

\section{References}

Andelt, W.F., 1992. Effectiveness of livestock guarding dogs for reducing predation on domestic sheep. Wildl. Soc. Bull. 20, 55-62.

Andelt, W.F., 1999. Relative effectiveness of guarding-dog breeds to deter predation on domestic sheep in Colorado. Wildl. Soc. Bull. 27, 706-714.

Andelt, W.F., Hopper, S.N., 2000. Livestock guard dogs reduce predation on domestic sheep in Colorado. J. Range Manage. 53, 259-267.

Arons, C., 1980. Raising livestock guarding dogs. Sheep Canada Fall, 5-7.

Atwood, T.C., DeLiberto, T.J., Smith, H.J., Stevenson, J.S., VerCauteren, K.C., 2009. Spatial ecology of raccoons related to cattle and bovine tuberculosis in northeastern Michigan. J. Wildl. Manage. 73, 647-654.

Bangs, E., Jimenez, M., Niemeyer, C., Fontaine, J., Collinge, M., Krsichke, R., Handegard, L., Shivik, J., Sime, C., Nadeau, S., Mack, C., Smith, D.W., Asher, V., Stone, S., 2006. Non-lethal and lethal tools to manage wolflivestock conflict in the Northwestern United States. Proc. Vertebr. Pest Conf. 22, 7-16.

Bengis, R.G., Kock, R.A., Fischer, J., 2002. Infectious animal diseases: the wildlife/livestock interface. Rev. Sci. Tech. Off. Int. Epizoot. 21, 53-65.

Beringer, J., Hansen, L.P., Heinen, R.A., Giessman, N.F., 1994. Use of dogs to reduce damage by deer to a white pine plantation. Wildl. Soc. Bull. $22,627-632$.

Castelli, P.M., Sleggs, S.E., 2000. Efficacy of border collies to control nuisance Canada geese. Wildl. Soc. Bull. 28, 385-392.

Coppinger, R., Lorenz, J., Coppinger, L., 1987. New uses of livestock guarding dogs to reduce agriculture/wildlife conflicts. In: Proc. East. Wildl. Damage Control Conf., 3, pp. 253-259.

Coppinger, R., Coppinger, L., Langeloh, G., Gettler, L., Lorenz, J., 1988. A decade of use of livestock guarding dogs. In: Proc. Vertebr. Pest Conf., 13, pp. 209-214.

Curtis, P., Rieckenberg, R., 2005. Use of dogs for reducing deer damage in apple orchards. In: Proc. Wildl. Damage Manage. Conf., 11, pp. 149-158.

Edge, J.L., Beyer Jr., D.E., Belant, J.L., Jordan, M.J., Roell, J., 2011. Livestock and domestic dog predations by wolves in Michigan. Hum. Wildl. Interact. 5, 66-78.

Espuno, N., Lequette, B., Poulle, M., Migot, P., Lebreton, J., 2004. Heterogeneous response to preventive sheep husbandry during wolf recolonization of the French Alps. Wildl. Soc. Bull. 32, 1195-1208.

Fox, M.W., Stelzner, D., 1966. Behavioural effects of differential early experience in the dog. Anim. Behav. 14, 273-281.

Freedman, D.G., King, J.A., Elliot, O., 1961. Critical period in the social development of dogs. Science 133, 1016-1017.
Gehring, T.M., Potter, B.A., 2005. Wolf habitat analysis in Michigan: an example of the need for proactive land management for carnivore species. Wildl. Soc. Bull. 33, 1237-1244.

Gehring, T.M., Hawley, J.E., Davidson, S.J., Rossler, S.T., Cellar, A.C., Schultz, R.N., Wydeven, A.P., VerCauteren, K.C., 2006. Are viable non-lethal management tools available for reducing wolf-human conflict? Preliminary results from field experiments. In: Proc. Vertebr. Pest Conf., 22, pp. 2-6.

Gehring, T.M., VerCauteren, K.C., Landry, J.-M., 2010a. Livestock protection dogs in the 21st century: is an ancient tool relevant to modern conservation challenges? BioScience 60, 299-308.

Gehring, T.M., VerCauteren, K.C., Provost, M.L., Cellar, A.C., 2010b. Utility of livestock protection dogs for deterring wildlife from cattle farms. Wildl. Res. 37, 715-721.

Gehring, T.M., Cellar, A.C., VerCauteren, K.C., 2010c. Good fences make good neighbors: implementation of electric fencing for establishing effective livestock protection dogs. Hum. Wildl. Interact. 5, 106-111.

Gortazar, C., Vicente, J., Samper, S., Garrido, J.M., Fernández-De-Mera, I.G., Gavín, P., Juste, R.A., Martín, C., Acevedo, P., De La Puente, M., Höfle, U., 2005. Molecular characterization of Mycobacterium tuberculosis complex isolates from wild ungulates in south-central Spain. Vet. Res. $36,43-52$.

Gortazar, C., Ferroglio, E., Höfle, U., Frölich, K., Vicente, J., 2007. Diseases shared between wildlife and livestock: a European perspective. Eur. J. Wildl. Res. 53, 241-256.

Green, J.S., Woodruff, R.A., Tueller, T.T., 1984. Livestock-guarding dogs for predator control: costs, benefits, and practicality. Wildl. Soc. Bull. 12, $44-50$.

Green, J.S., Woodruff, R.A., 1988. Breed comparisons and characteristics of use of livestock guarding dogs. J. Range Manage. 41, 249-250.

Green, J.S., Woodruff, R.A., 1990. ADC guarding dog program update: a focus on managing dogs. In: Proc. Vertebr. Pest Conf., 14, pp. 233-236.

Green, J.S., Woodruff, R.A., 1999. Livestock guarding dogs: protecting sheep from predators. U.S. Department of Agriculture. Agric. Inform. Bull., 588.

Hansen, I., Bakken, M., 1999. Livestock-guarding dogs in Norway: part I. Interactions. J. Range Manage. 52, 2-6.

Hansen, I., Smith, M.E., 1999. Livestock-guarding dogs in Norway: part II. Different working regimes. J. Range Manage. 52, 312-316.

Harper, E.K., Paul, W.J., Mech, L.D., 2005. Causes of wolf depredation increase Minnesota from 1979-1998. Wildl. Soc. Bull. 33, 888-896.

Hawley, J.E., Gehring, T.M., Schultz, R.N., Rossler, S.T., Wydeven, A.P., 2009. Assessment of shock collars as nonlethal management for wolves in Wisconsin. J. Wildl. Manage. 73, 518-525.

Harrison, A., Newey, S., Gilbert, L., Haydon, D.T., 2010. Culling wildlife hosts to control disease: mountain hares, red grouse and louping ill virus. J. Appl. Ecol. 47, 926-930.

Idaho Rangeland Resource Commission, 2010. Fact Sheet on the BLM's Management of Livestock Grazing. Emmett, Idaho, USA.

Landry, J.M., 1999. The Use of Guard Dogs in the Swiss Alps: A First Analysis. KORA Report No 2., http://www.kora.ch.

Landry, J.M., Burri, A., Torriani, D., Angst, C., 2005 January. Livestock guarding dogs: a new experience for Switzerland. Carnivore Damage Prev. News, 40-48.

Landry, J.M., Raydelet, P., 2010. Efficacité des chiens de protection contre la prédation du lynx dans le Massif jurassien. Report for the French Ministry of Environment. Pôle Grand Prédateur, Juin 2010. http://www.polegrandspredateurs.org (accessed 23.02.11).

Lee, C., Prayaga, K., Reed, M., Henshall, J., 2007. Methods of training cattle to avoid a location using electrical cues. Appl. Anim. Behav. Sci. 108, 229-238.

Lorenz, J.R., Coppinger, L., 1987. Raising and training a livestockguarding dog. Oregon State University Extension Service, Publication EC 1238.

Marker, L.L., Dickman, A.J., Macdonald, D.W., 2005. Perceived effectiveness of livestock-guarding dogs placed on Namibian farms. Rangeland Ecol. Manage. 58, 329-336.

Mech, L.D., Fritts, S.H., Wagner, D., 1995. Minnesota wolf dispersal to Wisconsin and Michigan. Am. Midl. Nat. 133, 368-370.

Messerschmidt, D.A., 1983. The Tibetan mastiff: canine sentinels of the range. Rangelands 5, 172-174.

Miller, M.W., Williams, E.S., Hobbs, N.T., Wolfe, L.L., 2004. Environmental sources of prion transmission in mule deer. Emerg. Infect. Dis. 10, 1003-1006.

O’Brien, D.J., Schmitt, S.M., Fitzgerald, S.D., Berry, D.E., Hickling, G.J., 2006. Managing the wildlife reservoir of Mycobacterium bovis: the Michigan. USA, experience. Vet. Microbiol. 112, 313-323. 
Palmer, M.V., Whipple, D.L., Waters, R., 2001. Experimental deer-todeer transmission of Mycobacterium bovis. Am. J. Vet. Res. 62, 692-696.

Palmer, M.V., Waters, W.R., Whipple, D.L., 2004. Shared feed as a means of deer-to-deer transmission of Mycobacterium bovis. J. Wildl. Dis. 40, 87-91.

Palmer, M.V., Whipple, D.L., 2006. Survival of Mycobacterium bovis on feedstuffs commonly used as supplemental feed for white-tailed deer (Odocoileus virginianus). J. Wildl. Dis. 42, 853-858.

Rhyan, J.C., Spraker, T.R., 2010. Emergence of diseases from wildlife reservoirs. Vet. Pathol. 47, 34-39.

Rigg, R., 2001. Livestock guarding dogs: Their current use worldwide. IUCN/SSC Canid Specialist Group Occasional Paper No. 1, http://www.canids.org/occasionalpapers/ (accessed 23.2.11).

Rigg, R., 2004. The extent of predation on livestock by large carnivores in Slovakia and mitigating carnivore-human conflict using livestock guarding dogs. Thesis, University of Aberdeen, Aberdeen City, UK.

Rossler, S.T., Gehring, T.M., Schultz, R.N., Rossler, M.T., Wydeven, A.P., Hawley, J.E., 2012. Shock collars as a site-aversive conditioning tool for wolves. Wildl. Soc. Bull. 36, 176-184.

Rushen, J., 1986. The validity of behavioural measures of aversion: a review. Appl. Anim. Behav. Sci. 16, 309-323.

Schilder, M.B.H., van der Borg, J.A.M., 2004. Training dogs with help of the shock collar: short and long term behavioural effects. Appl. Anim. Behav. Sci. 85, 319-334.

Schultz, R.N., Jonas, K.W., Skuldt, L.H., Wydeven, A.P., 2005. Experimental use of dog-training shock collars to deter depredation by gray wolves. Wildl. Soc. Bull. 33, 142-148.

Scott, J.P., 1962. Genetics and the development of social behavior in mammals. Am. J. Orthopsychiatry 32, 878-893.
Scott, J.P., Fuller, J.L., 1965. Genetics and the Social Behavior of the Dog University of Chicago Press, USA.

Seward, N.W., Phillips, G.E., Duquette, J.F., VerCauteren, K.C., 2007. A frightening device for deterring deer use of cattle feeders. J. Wildl. Manage. 71, 271-276.

Shivik, J.A., 2006. Tools for the edge: what's new for conserving carnivores. BioScience 56, 253-259.

Sims, D.E., Dawydiak, O., 2004. Livestock Protection Dogs: Selection, Care, and Training, 2nd ed. Alpine Blue Ribbon Books, Loveland, CO, USA.

Urbigkit, C., Urbigkit, J., 2010. A review: the use of livestock protection dogs in association with large carnivores in the Rocky Mountains. Sheep Goat Res. J. 25, 1-8.

Van Campen, H., Rhyan, J., 2010. The role of wildlife in diseases of cattle. Vet. Clin. N. Am. Food Anim. Pract.: Emerg. Reemerg. Persistent Infect. Dis. Cattle 26, 147-161.

VerCauteren, K.C., Pipas, M., Peterson, P., Beckerman, S., 2003. Stored-crop loss due to deer consumption. Wildl. Soc. Bull. 31, 578-582.

VerCauteren, K.C., Seward, N.W., Hirchert, D.L., Jones, M.L., Beckerman, S.F., 2005. Dogs for reducing wildlife damage to organic crops: a case study. In: Proc. Wildl. Damage Manage. Conf., 11, pp. 286-293.

VerCauteren, K.C., Lavelle, M.J., Phillips, G.E., 2008a. Livestock protection dogs for deterring deer from cattle and feed. J. Wildl. Manage. 72, 1443-1448.

VerCauteren, K.C., Atwood, T.C., DeLiberto, T.J., Smith, H.J., Stevenson, J.S., Thomsen, B.V., Gidlewski, T., Payeur, J., 2008b. Sentinel-based surveillance of coyotes to detect bovine tuberculosis, Michigan. Emerg. Infect. Dis. $14,1862-1869$.

Woodruff, R.A., Green, J.S., 1995. Livestock herding dogs: a unique application for wildlife damage management. In: Proc. Great Plains Wildl. Damage Control Workshop, 12, pp. 43-45. 